\title{
Electricity Production from Sugarcane Straw Recovered Through Bale System: Assessment of Retrofit Projects
}

\author{
Isabelle L. M. Sampaio ${ }^{1,2} \cdot$ Terezinha F. Cardoso $^{1} \cdot$ Nariê R. D. Souza $^{1,2} \cdot$ Marcos D. B. Watanabe $^{1,2} \cdot$ Danilo J. Carvalho $^{1} \cdot$ \\ Antonio Bonomi ${ }^{1,3} \cdot$ Tassia Lopes Junqueira ${ }^{1,2}$ (B)
}

Published online: 26 July 2019

(C) The Author(s) 2019

\begin{abstract}
Sugarcane straw has become available in large quantities in the field due to transition from manual to mechanical harvesting. Straw can be used as fuel for cogeneration systems of sugarcane mills to increase surplus electricity for commercialization. However, the exploitation of straw potential is still limited due to some challenges related to its agricultural recovery and industrial processing. The retrofit (additional installation) of existing sugarcane mills to process straw is an alternative to reduce investment and to allow a gradual utilization of this biomass. In this work, techno-economic and environmental assessment of straw recovery through bale system to increase electricity export was assessed. Two scenarios with straw recovery and processing were defined to take advantage of an existing cogeneration system, considering its operation in the season and off-season periods. An increase of up to $57 \%$ on surplus electricity was achieved. Both scenarios resulted in economically feasible alternatives. However, results were very sensitive to the variations on electricity prices and straw costs. In terms of environmental benefits, the bioelectricity presented a great potential to mitigate greenhouse gas emissions compared with natural gas-based electricity. The higher electricity surplus also affects the carbon intensity of ethanol, which can lead to indirect gains when the Brazilian program for biofuels incentive is implemented.
\end{abstract}

Keywords Sugarcane straw $\cdot$ Bale system $\cdot$ Electricity $\cdot$ Economic assessment $\cdot$ Greenhouse gas Emissions

\section{Introduction}

In Brazil, a transition from manual to mechanical harvesting has been observed in the sugarcane sector, especially in the Center-South region of Brazil. This transition was motivated by legislation prohibiting sugarcane pre-harvesting burning and other economic, social, and environmental issues related to the manual harvesting $[1,2]$. Nowadays, mechanical harvesting in this region has reached $97 \%$ of the crop area [3].

Tassia Lopes Junqueira

tassia.junqueira@ctbe.cnpem.br

1 Laboratório Nacional de Biorrenováveis (LNBR), Centro Nacional de Pesquisa em Energia e Materiais (CNPEM), Campinas, São Paulo 13083-970, Brasil

2 Programa Integrado de Pós-Graduação em Bionergia, Faculdade de Engenharia de Alimentos (FEA), Universidade Estadual de Campinas (Unicamp), Rua Monteiro Lobato 80, Campinas, São Paulo 13083-862, Brasil

3 Faculdade de Engenharia Química (FEQ), Universidade Estadual de Campinas (Unicamp), Av. Albert Einstein, 500, Campinas, São Paulo 13083-852, Brasil
Cardoso et al. [1] compared scenarios with manual and mechanical harvesting. In terms of green (non-burned) cane harvesting, mechanization presented lower sugarcane production costs. Also, changing from manual harvesting of burned cane to mechanical harvesting of green cane, a reduction on climate change impacts was observed due to the decrease of greenhouse gases emissions and particulate material associated with the sugarcane pre-harvesting burning.

As a consequence of burning restrictions, the straw, composed by sugarcane green tops ( $40 \%)$ and dry leaves $(60 \%)$, is abundantly available in the field [2]. Considering the CenterSouth region-with a production equivalent to 567 million tonnes of sugarcane per year, which corresponds to more than $90 \%$ of Brazilian sugarcane production [3] - the amount of straw produced would be higher than 70 million tonnes (dry basis). This biomass has potential applications to both agricultural and industrial stages.

For instance, the straw left in the soil is used as a cover, which can contribute to soil organic matter increase, water storage, control of weed infestation and soil erosion, carbon accumulation and nutrient recycling $[2,4,5]$. However, large amounts of straw in the soil, besides offering a fire risk, 
increase the proliferation of pests and can result in slower regrowth of ratoon in colder regions compromising the crop development initial stage [6-9]. According to Marin et al. [10], sandy soils with water deficit are negatively responsive to straw removal. Carvalho et al. [4] indicate the permanence of $7 \mathrm{t}$ of straw (on a dry basis) per hectare in the soil but highlight the need to evaluate the climate and soil conditions to adequately determine this amount.

As a lignocellulosic material, straw has several potential applications, including production of electricity [1, 11], biofuels [12, 13], and biochemicals [14, 15]. Part of this biomass is normally recovered along with sugarcane stalks (as vegetable impurities), but strategies to recover higher proportions have been proposed such as integral harvesting and baling $[1,16-18]$. The integral harvesting consists of recovering a larger fraction of straw by reducing the harvester's primary extractor speed so that the straw is harvested, chopped, and transported along with the sugarcane stalks. On the other hand, baling is a recovery method where straw is windrowed around 10-15 days after harvesting, collected, and compacted in bales by a specific implement; after that, bales are transported separately from the stalks to the mill [1]. Cardoso et al. [16] compared both recovery methods and found that integral harvesting results in lower sugarcane straw costs, but it is associated with a higher complexity in industrial operations, since an additional cleaning system (for straw removal) is required so that the extraction of sugars is less impacted. For this reason, both routes can be competitive, and the choice will depend on particular conditions of the sugarcane mill.

Nevertheless, the exploitation of straw potential is still limited. The main reasons include agronomic implications [4, 19], development level of systems related to straw recovery and processing $[16,17]$, lack of investments in the sector [20], and low electricity price in regulated markets [21, 22]. In this context, the SUCRE (Sugarcane Renewable Electricity) Project (n.d.) [23] - under development at LNBR/CNPEM - is collecting more data through agricultural and industrial experiments in order to provide information and evaluate solutions for these challenges. In addition, a comprehensive assessment of straw exploitation considering economic, environmental, and social impacts has also been performed in the project using partner mills as case studies.

The present work focuses on the economic and environmental assessment of straw recovery through bale system to increase electricity export in retrofit projects, i.e., complementary installations for straw processing in existing sugarcane mills. The assessment is carried out using the Virtual Sugarcane Biorefinery (VSB), a computational framework for simulation and sustainability assessment of biorefineries that considers the entire sugarcane production chain [24]. Several aspects related to straw recovery and processing are taken into account for the scenario's definition and evaluation, considering the experience of the partner mills from the
SUCRE Project. In addition, comments on the observed challenges that hinder a more expressive utilization of straw are presented in the "Discussion" section.

\section{Material and Methods}

\section{Agroindustrial Modeling}

For the correct evaluation of the effects of increasing the recovery of straw on an existing sugarcane mill, an integrated analysis (considering both industrial and agricultural phases) is necessary to assess the environmental and economic impacts of this practice. The VSB is a platform that is suited for this purpose performing environmental, economic, and social analysis using data from computer simulation models. This platform has been applied in previous studies to evaluate second-generation ethanol in current and future scenarios [12] and biodigestion of vinasse for biogas production [25], among other studies.

For the industrial modeling, a commercial process simulator (AspenPlus $®$ ) was employed. These simulations are used to determine the mass and energy balances of the investigated industrial scenarios. In order to assess the impact of straw, simulations without and with straw recovery were performed. The results were used as inputs for the estimation of operational expenditures (OPEX) and capital cost (CAPEX) in the economic analysis and for the life cycle inventory for environmental assessment.

The straw recovery costs were determined using Canasoft model, a set of electronic spreadsheets developed by LNBR, which contains an agronomic and agricultural database. It allows calculating the total production cost of a given biomass considering the agricultural operations, chemical inputs, fertilizers, pesticides, and labor, among other important items in the composition of the total cost of biomass [26]. In this study, only the costs associated with additional operations in the agricultural system were taken into account, which, for straw recovery through baling system, include windrowing, collection and compaction in bales, loading, and transportation to the mill. These costs are considered in the industrial cash flows as the annual operating costs associated with biomass. In addition, Canasoft model provides information for the life cycle inventory for environmental assessment.

\section{Economic Assessment}

A discounted cash flow analysis was carried out considering retrofit industrial projects. In this assessment, only incremental flows related to the additional straw recovery and processing for electricity production are considered. The metrics considered in this paper are the net present value (NPV), 
Table 1 Main assumptions of the techno-economic assessment

\begin{tabular}{ll}
\hline Item & Value \\
\hline Expected project life time & 20 years \\
Discount rate & $12 \%$ per year \\
Reference date & November 2018 \\
Exchange rate & 3.79 BRL per US\$ \\
Depreciation & 10 years, linear \\
Electricity price & US $\$ 54$ per MWh \\
\hline
\end{tabular}

incremental internal rate of return (IRR), and minimum selling price (MSP) of electricity.

The NPV is an indicator of how much value an investment or project adds to the firm or business. When NPV $\geq 0$, the alternative is feasible because value is added to the firm. The internal rate of return (IRR) is the average interest rate paid per year by the evaluated project. The IRR of an investment is the discount rate at which the net present value of costs (negative cash flows) of the investment equals the net present value of the benefits (positive cash flows) of the investment. In other words, IRR can be found when NPV equals zero. Finally, the minimum selling price (MSP), or levelized cost of electricity, is the minimum value by which electricity can be sold in order to reach the minimum feasibility situation, i.e., when NPV is zero.

The main assumptions of the techno-economic assessment are described in Table 1, according to typical values for Brazilian sugarcane industry [27]. The electricity price represents the historical average price in the regulated market for a decade in Brazil [21]. The discounted cash flow analysis was performed according to electronic spreadsheets and data from the VSB. The total capital expenditures (CapEx) considered the additional equipment and infrastructure for straw processing, based on information provided by industrial partners of the SUCRE Project. Also, chemicals, labor, and maintenance were calculated according to typical values for local sugarcane industry [27]. The straw recovery costs were generated in Canasoft model, which integrates all the costs involved to collect straw in the field and transport it to the industry.

\section{Environmental Assessment}

The environmental assessment was performed under the life cycle assessment (LCA) methodology, considering ISO 14040 and ISO 14044, and climate change impact ( $\mathrm{g}$ $\mathrm{CO}_{2}$ eq) per megajoule of ethanol and per kilowatt-hour of electricity produced. In the LCA methodology, the whole production chain of a certain process/product is considered.

In this work, a cradle-to-gate assessment was performed (Fig. 1) considering energetic allocation to attribute overall emissions from the assessed system among all products (sugar, ethanol, and electricity). The inventory was built based on VSB database and agroindustrial simulations [27].
After the attributional LCA, we calculated the avoided emissions assuming the bioelectricity produced would replace electricity from natural gas. Such avoided greenhouse gas (GHG) emissions were calculated as the difference among carbon intensity (CI) of electricity produced from the two different sources. We assumed a CI of $550.8 \mathrm{~g} \mathrm{CO}_{2} \mathrm{eq} / \mathrm{kWh}$ of electricity from natural gas according to ecoinvent database [28]; the CI for sugarcane bioelectricity is derived from the LCA performed and varies according to the results of each scenario.

Similarly, the avoided emissions related to sugarcane ethanol replacing gasoline were calculated based on the difference of the $\mathrm{CI}$ of gasoline, equals to $87.4 \mathrm{~g} \mathrm{CO}_{2}$ eq/MJ [29], and the CI of ethanol also derived from the LCA performed; the emissions from the distribution and use of ethanol were included (cradle-to-grave approach, Fig. 1) in order to be compared with gasoline.

\section{Scenario Definition}

The amount of straw available depends on several factors, such as sugarcane variety, cutting stage and sugarcane productivity, type of soil, and climate of the region, among others, ranging from 10 to 20 tonnes per hectare [30].

In this study, scenarios consider an agricultural yield of 75 tonnes of harvested stalks per hectare, equivalent to the average of Center-South region in 2017/2018 season [3]. Main assumptions for agricultural modeling include fully mechanized harvest of green cane, considering a $10 \%$ loss of sugarcane stalks due to inefficiencies of harvesting process, average transport distance of $37 \mathrm{~km}$, and production of $140 \mathrm{~kg}$ of straw (dry basis) per tonne of sugarcane stalk produced [18], totalizing 11.7 tonnes of straw (dry basis) per hectare.

A 5\% vegetable impurity in the sugarcane stalks load was considered, which corresponds to $16 \%$ of the produced straw per hectare. Between 10 and 15 days after harvest, the moisture of straw is reduced to about $15 \%$ and an additional amount of straw is collected through bale system, assuming balers with effective working period of $5 \mathrm{~h}$ per day. Straw recovery cost with bales is calculated as the additional costs per hectare of scenario with straw recovery in comparison with the scenario without straw recovery [31].

In this study, the following scenarios were defined to evaluate the economic and environmental feasibility of increasing the recovery of sugarcane straw on an existing sugarcane mill. The retrofit of existing facilities to process straw is an alternative to reduce investment and to allow a gradual utilization of this biomass.

Baseline The design chosen as baseline is an annexed plant, producing anhydrous ethanol and sugar (50\% of sugarcane juice for each product), with an annual sugarcane crushing capacity of 4 million tonnes, operating 200 days (season period). The configuration chosen for this industrial facility 


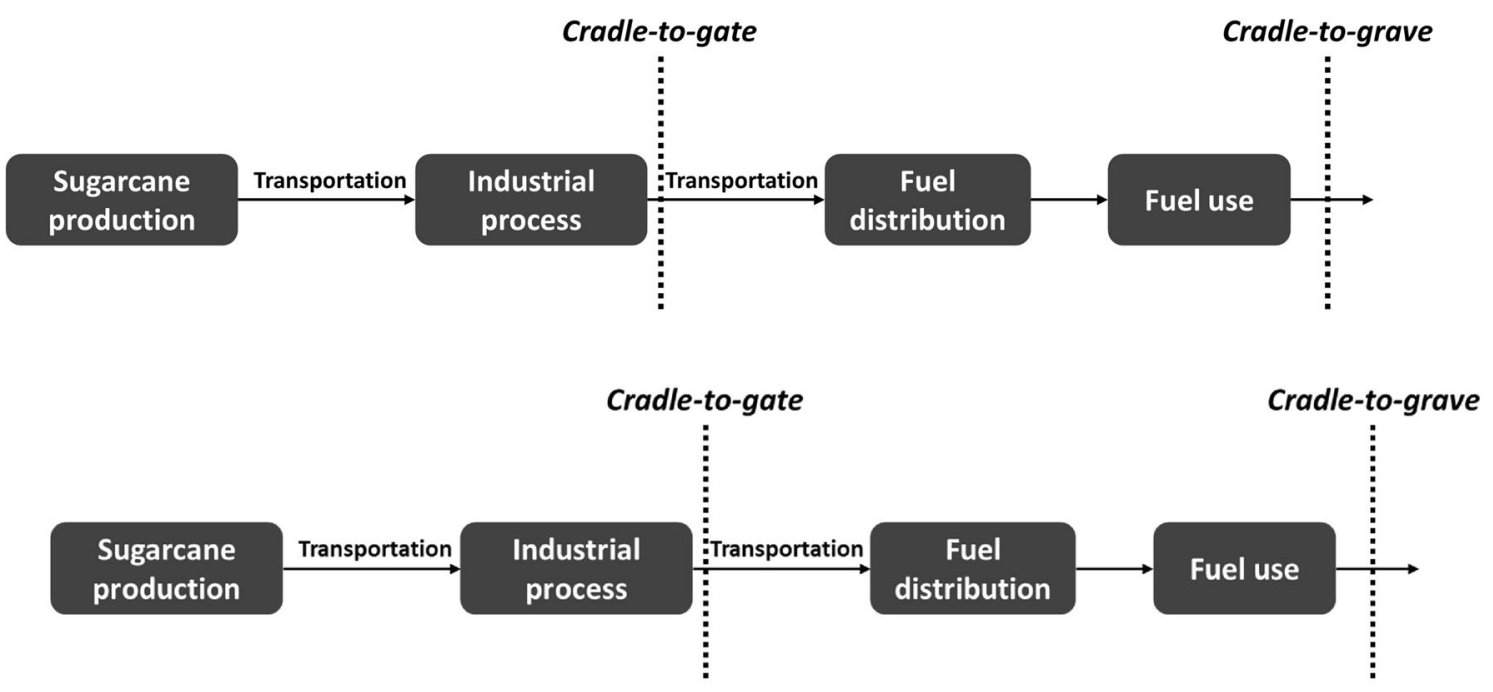

Fig. 1 System boundaries for the LCA of electricity (cradle-to-gate) and ethanol (cradle-to-grave) production

(electrified mills, three boilers with high pressure, two backpressure turbines, and one extraction-condensing turbine) would probably be found on a sugarcane mill that is already looking at increasing its electricity output [32]. The steam demand of the sugarcane mill is of around $500 \mathrm{~kg}$ of steam per tonne of sugarcane processed and the method of ethanol dehydration is azeotropic distillation, considered according to the typical consumption of steam practiced in a conventional mill [33]. No additional recovery of straw takes place; thus, only vegetable impurities - sugarcane tops and leaves that could not be separated by the harvester - are sent to the industrial facility along with sugarcane stalks. Figure 2 shows a simplified diagram of a sugarcane mill producing sugar, ethanol, and electricity with a more detailed view of the cogeneration sector of the plant.

Scenario 1 For this scenario, it was assumed that the cogeneration system was not operating at full capacity on the baseline; e.g., an idle capacity of $10 \%$ was considered for the boilers, and the turbines would be able to expand the respective additional steam. The amount of straw recovered from the field was calculated to fully occupy the idle capacity of the boilers. The only additional equipment considered was the one directly related to straw processing (unbaling system and choppers, transportation belts, among others).

Scenario 2 For this scenario, besides occupying the idle capacity of the boilers in the season, an additional time of operation of the cogeneration sector of the sugarcane mill was assumed (130 days). This period includes situations during the season where only the cogeneration sector is functional due to operational problems (e.g., those related to sugarcane extraction), or lack of feedstock (raining days when sugarcane harvest is momentarily stopped). During this period (referred to as off-season), only one out of the three boilers available operates and only the condensing-extracting turbine is used, operating almost on full condensing mode. The amount of straw recovered from the field was calculated according to these premises, and as in scenario 1, only additional equipment for the processing of the straw was required.

For scenarios 1 and 2, boilers were assumed to operate stably with the mixture of straw and bagasse. On previous studies using the VSB framework, higher efficiencies were assumed for boilers and turbogenerators as provided by equipment suppliers [12, 31]; however, in the present work, lower values were adopted in an attempt to better represent operating sugarcane mills, since efficiencies oscillate according to operation conditions. Table 2 presents the main industrial parameters of straw processing and cogeneration system, and Fig. 3 shows a diagram of the operation of the cogeneration sector of the sugarcane mill during season and off-season.

\section{Results and Discussion}

\section{Techno-economic Results}

Figure 4 highlights the main cost components of straw recovery, considering two amounts of straw recovered per hectare. The straw recovery cost with the bale system depends on the amount of straw recovered per hectare; e.g., increasing from 3 to $5 \mathrm{t}_{\mathrm{db}} / \mathrm{ha}$, the cost is reduced from US\$37 to US\$27 per tonne (dry basis), which corresponds to a $26 \%$ reduction. Small amounts of straw per hectare are associated with low operational efficiency of the machinery (mainly the baler), which increases the straw recovery cost [16]. The transport distance is a parameter that has a smaller participation in the costs of straw recovery with bales due to straw compaction [31]. In this study, the straw cost for recovery of $3 \mathrm{t}_{\mathrm{db}}$ /ha was considered for the economic 


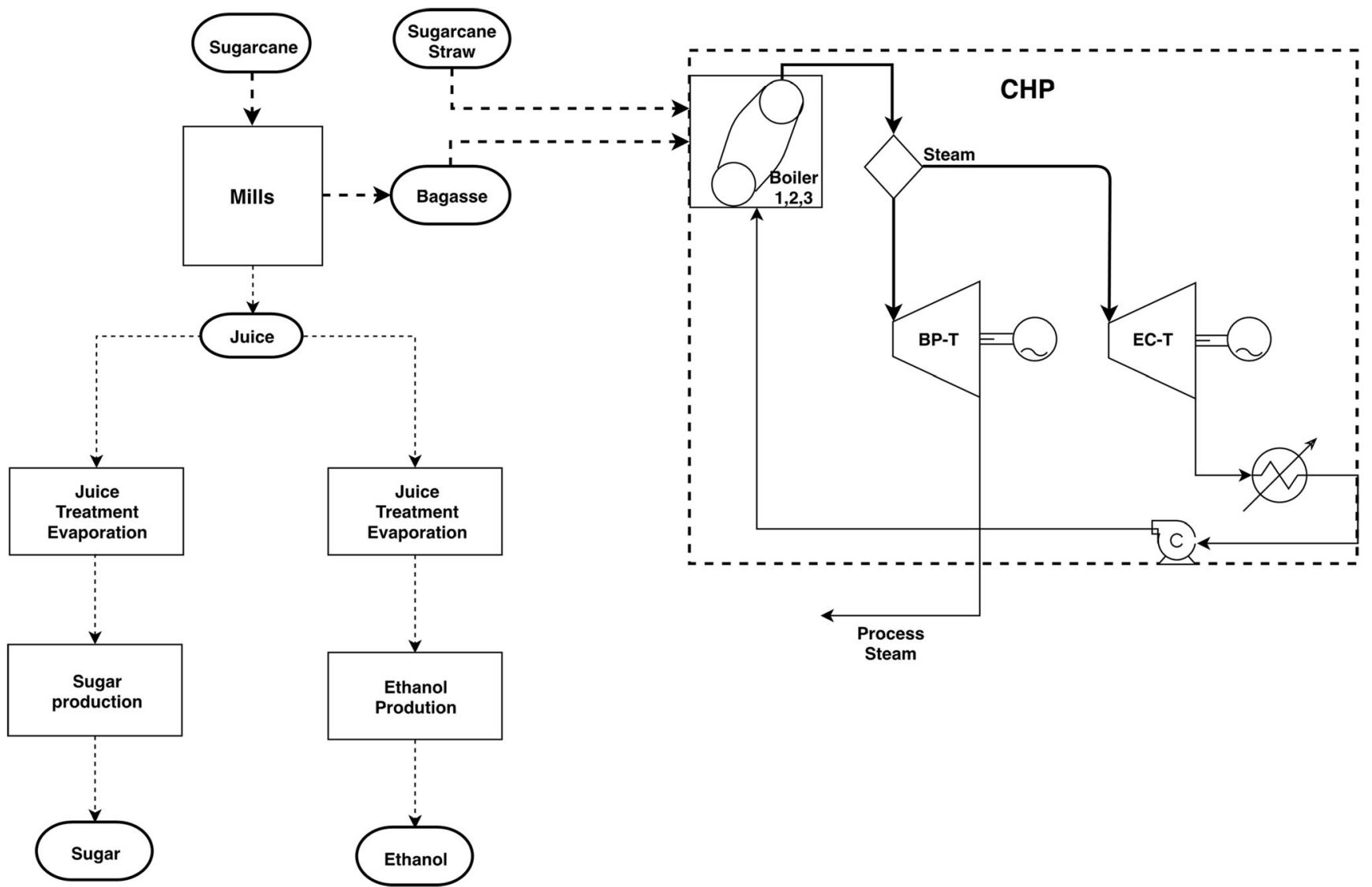

Fig. 2 Simplified diagram of a sugarcane mill producing sugar, ethanol, and electricity

analysis for scenarios 1 and 2, since it allows maintaining in the soil around 7 tonnes of straw (dry basis) per hectare, as indicated by Carvalho et al. [17]. It is worth to mention that scenarios 1 and 2 have different quantities of straw processed in the industry, so the recovery area differs between both scenarios, but assuming the same average of transport distance.

The main industrial results obtained are shown in Table 3. As straw recovered from bales are processed and sent directly to cogeneration, there is no impact on sugar and ethanol production processes; thus, no change on both products' output was observed.
The electricity surplus for the baseline reported in Table 3 is of $70.8 \mathrm{kWh}$ per tonne of sugarcane. This result is comparable with one of the case studies presented by Alves et al. [11], where an electricity surplus of $77.5 \mathrm{kWh} / \mathrm{t}$ cane is reported. The electricity surplus is also very close to the value reported (69.6 kWh/t of sugarcane) by Olivério and Ferreira [32] for a similar sugarcane mill configuration. The electricity export presented for the baseline is also coherent with the values reported for real sugarcane mills on PECEGE [34], where newer units or units redesigned for better cogeneration performance had a surplus of electricity between 40 and $80 \mathrm{kWh}$ per tonne of sugarcane processed.

Table 2 Industrial parameters of straw processing and electricity production and demand

\begin{tabular}{llll}
\hline & Baseline & Scenario 1 & Scenario 2 \\
\hline Equipment for straw processing & None & $\begin{array}{c}\text { Unbaling system, choppers, } \\
\text { additional transportation belts }\end{array}$ & $\begin{array}{c}\text { Unbaling system, choppers, } \\
\text { additional transportation belts }\end{array}$ \\
$\begin{array}{l}\text { Process electricity demand }(\mathrm{kWh} / \mathrm{t} \text { sugarcane, } \\
\quad \text { wet basis) }\end{array}$ & 30 & 30 & 30 \\
$\begin{array}{l}\text { Electricity demand for straw processing equipment } \\
\quad(\mathrm{kWh} / \mathrm{t} \text { straw, wet basis) }\end{array}$ & - & 25 & 25 \\
$\begin{array}{l}\text { Electricity demand for off-season operation } \\
\text { Boiler efficiency }\left(65 \text { bar, } 485^{\circ} \mathrm{C}\right)\end{array}$ & - & - & $8 \%$ of the generated electricity \\
Turbogenerator efficiency (steam turbines + generator) & $70 \%$ & $70 \%$ & $82 \%$ \\
\hline
\end{tabular}




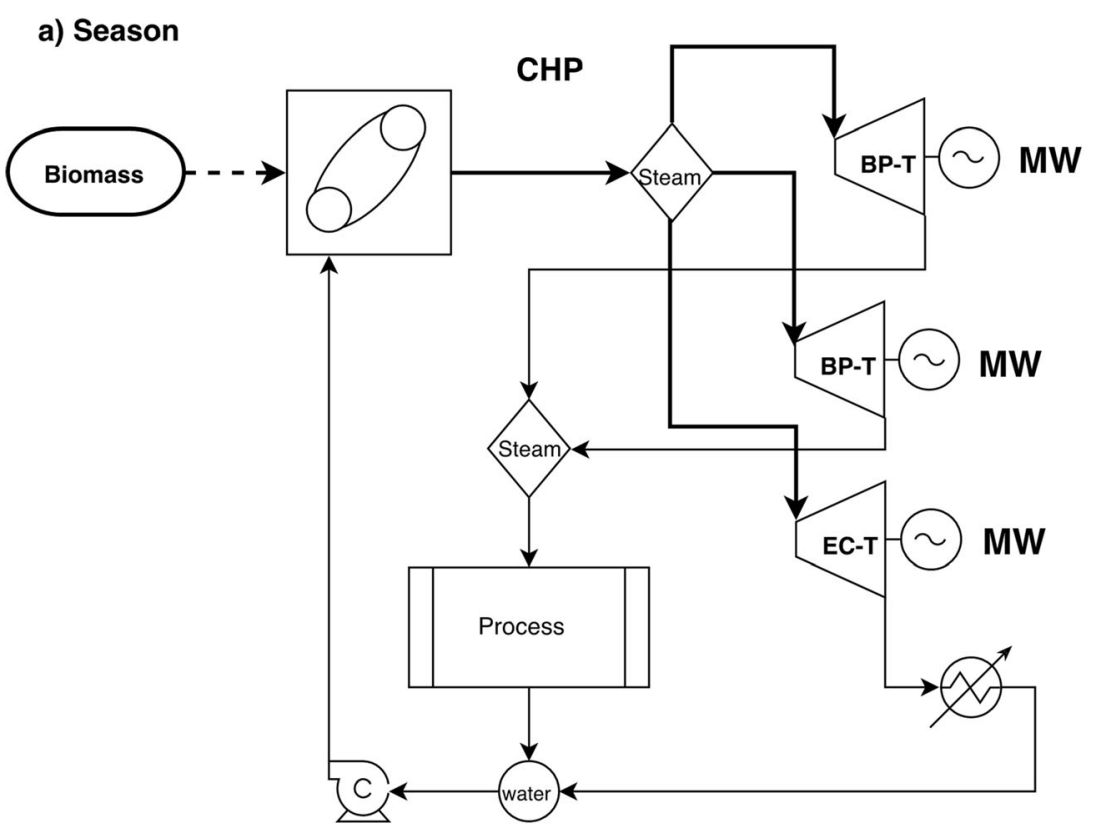

b) Off-Season

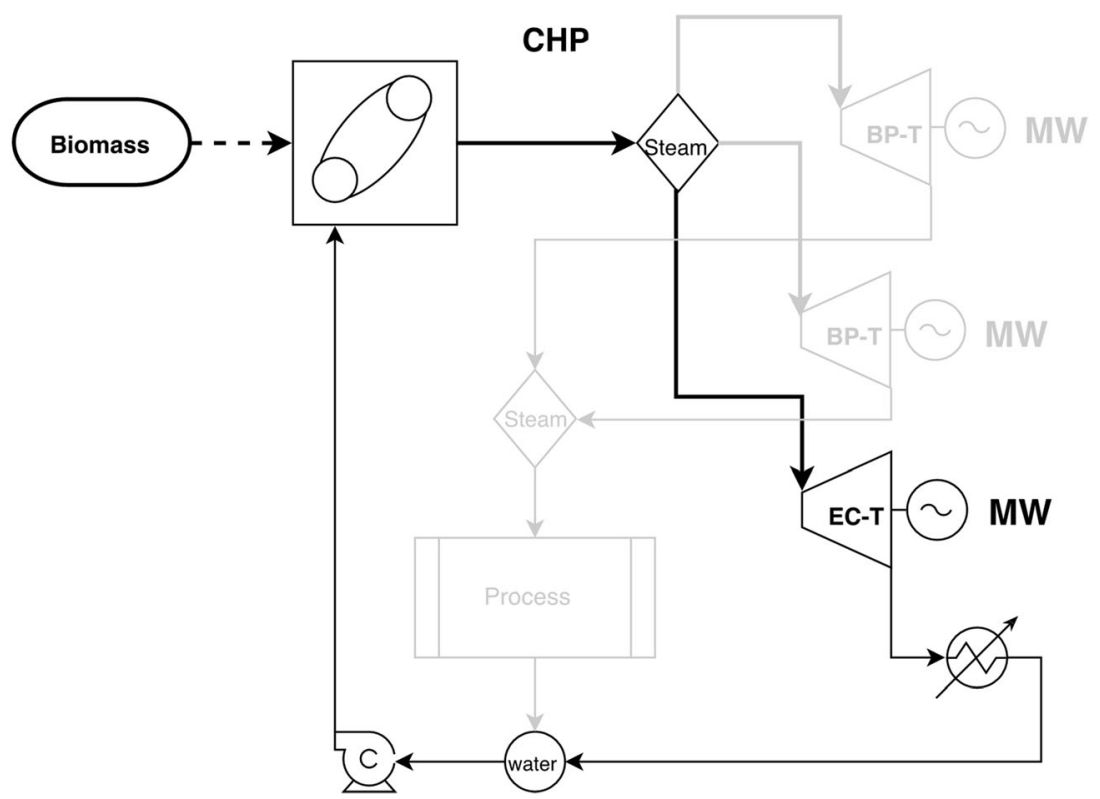

Fig. 3 Operation mode of the cogeneration system of the sugarcane mill: a in the season (baseline, scenarios 1 and 2); $\mathbf{b}$ in the off-season (scenario 2)

As expected, with the increase in straw available to burn at the industrial site, more electricity can be generated, if there is some idle capacity on the cogeneration sector of the sugarcane mill (i.e., equipment not operating on full capacity or if it can be operated for more days). The electricity demand increases from the baseline to scenario 1 , and even more to scenario 2. This is due to the additional power required for the operations related to sugarcane straw processing (chopping, removing the tying strings from bales, transporting, among others). The demand for all straw processing operations was adopted as $25 \mathrm{~kW}$ per tonne of sugarcane straw processed. In SUCRE Project experiments, values as high as $45 \mathrm{~kW} / \mathrm{t}$ have been observed; however, in most cases, the systems were not operating on full capacity and as a result consumed more energy per unit of biomass (i.e., the power demanded for some operations in bale processing is the same operating with full capacity or with a fraction of the capacity). In scenario 2, besides the energy required to process straw, an additional demand of energy was considered to operate the cogeneration sector during the off-season period (see Table 2). This resulted in a higher annual demand of energy for this scenario. 


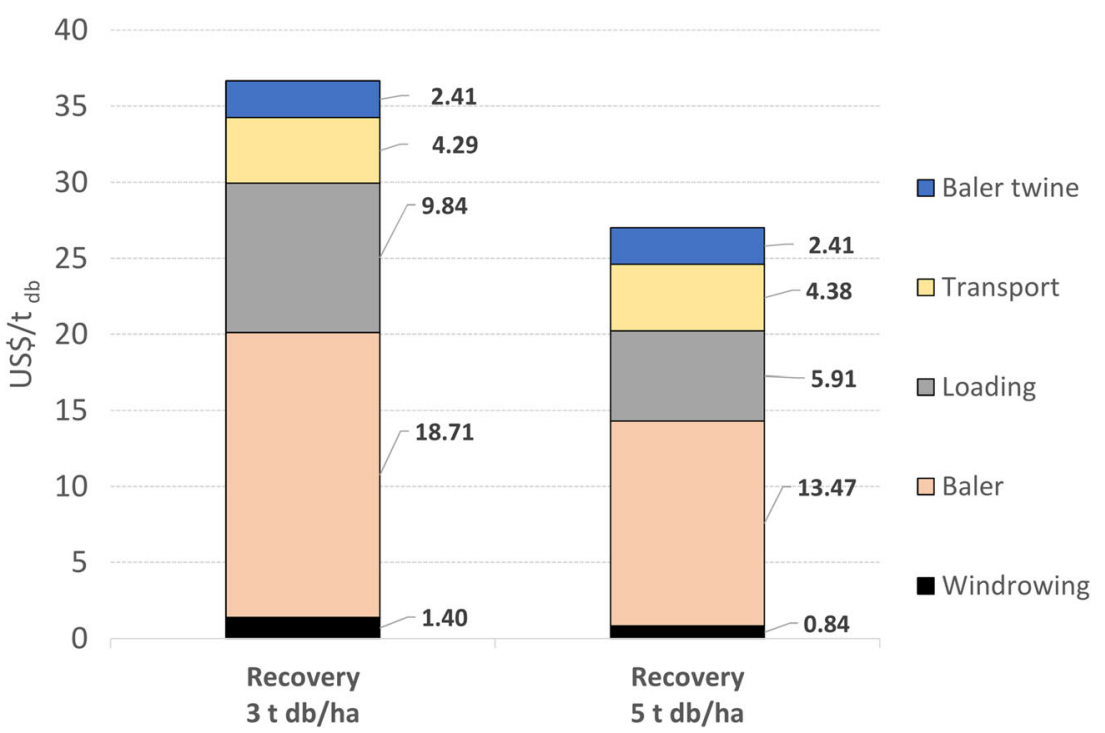

Fig. 4 Main components of straw recovery cost

Comparing the results reported in Table 3 , it is possible to observe that the electricity surplus increased $22 \%$ from the baseline to scenario 1 and around $57 \%$ from the baseline to scenario 2 . The amounts of straw recovered through bale system on scenario 1 and scenario 2 represent $9 \%$ and $27 \%$ of the total straw produced in the field, respectively.

In terms of economic assessment, the results from incremental cash flow analysis are shown in Table 4. Both scenarios present IRR significantly higher than the discount rate ( $12 \%$ per year) which indicates the economic viability of both incremental projects. Scenario 2 has a higher straw processing, which allows taking advantage from economies of scale in the CAPEX, whereas variable operating costs are proportional to the amount of processed straw. However, revenues from electricity in scenario 2 are proportionally lower (per amount of straw processed) due to the electricity consumption in the off-season and storage of part of the biomass for eventual process start-ups. Therefore, scenario 2 presents lower IRR and higher MSP of electricity than scenario 1.

Sensitivity analysis was performed to understand the impact on economic feasibility of straw recovery and processing, considering three main variables: straw cost, which is responsible for around $90 \%$ of annual operating costs in the incremental cash flow; electricity price; and CAPEX for the additional straw processing. A 50\% variation on the deterministic values was considered for the three variables. In the case of straw cost, a reduction of about $26 \%$ can be accomplished by varying the amount of straw recovered per hectare, as previously shown in this study. In the case of electricity, prices can differ significantly depending on the strategy of commercialization. Although auction prices are historically around US\$54 per megawatt-hour in the Brazilian regulated market (long-term contracts), the range of price volatility is higher in the short-term market (from US $\$ 10$ to 210 per MWh), which is heavily affected by changes in the Brazilian hydrological conditions [21]. For this reason, electricity prices were varied to represent changes in the project revenues. Project revenues would also be proportionally impacted if surplus electricity varies, which is dependent on boiler and turbine efficiencies and on electricity consumption in the straw processing and off-season operation. Uncertainties (of up to 50\%) were observed for CAPEX among the available data from the SUCRE Project, since there are different suppliers for straw unbaling system equipment.

Figure 5 presents the IRR results for the sensitivity analysis. As expected, there is a positive correlation with electricity revenues and negative correlations with straw cost and CAPEX. The highest sensitivity is observed between
Table 3 Main results for the industrial simulations

\begin{tabular}{lllc}
\hline & Baseline & Scenario 1 & Scenario 2 \\
\hline Sugarcane straw processed (dry basis) (kt/year) & - & 53.7 & 157.8 \\
Anhydrous ethanol production (ML/year) & 216.4 & 216.4 & 216.4 \\
Sugar production (kt/year) & 207.2 & 207.2 & 207.2 \\
Total electricity demanded for industrial operation (GWh/year) & 127.5 & 129.1 & 141.2 \\
Electricity surplus (GWh/year) & 283.3 & 345.4 & 443.7 \\
Electricity surplus (kWh/t of sugarcane) & 70.8 & 86.3 & 110.9 \\
\hline
\end{tabular}


Table 4 Results from incremental cash flow analysis

\begin{tabular}{lll}
\hline & Scenario 1 & Scenario 2 \\
\hline CAPEX (US\$ million) & 2.3 & 5.5 \\
Revenues (US\$ million) & 3.4 & 8.7 \\
OPEX (US\$ million) & 2.2 & 6.3 \\
Gross profit (US\$ million) & 1.1 & 2.3 \\
IRR (\%, per year) & 30.7 & 26.8 \\
NPV (US\$ million) & 3.5 & 13.9 \\
MSP of electricity (US\$/MWh) & 42.7 & 45.9 \\
\hline
\end{tabular}

electricity price and internal rate of return, reaching a maximum of $72 \%$ (for both scenarios) and minimum values are negative or even not calculated for variations between $30 \%$ and $-50 \%$. Straw cost and CAPEX presented similar trends and IRR values until $+30 \%$ variation, when the impacts of straw cost become more significant, reaching negative or non-calculated IRRs for scenario 2 .
A combined sensitivity analysis is presented for scenario 2 in Table 5, considering the simultaneous variations in both straw cost and electricity prices. Although very high values can be obtained (up to $102 \%$ ), IRR values lower than the discount rate $(12 \%)$ are obtained in 10 out of 25 cases. Considering the high impact of electricity prices on the results, we can infer that there is a higher risk embedded in this incremental project if electricity is traded in the short-term market, thus indicating the preference for longer contracts with more steady prices both in the free contracting environment (ACL) and regulated contracting environment (ACR) in Brazil.

\section{Environmental Impacts}

The environmental results are presented in Tables 6 and 7. The slight difference in agricultural emissions among the scenarios are basically associated with the balance between additional emissions due to straw recovery operations (mostly related to

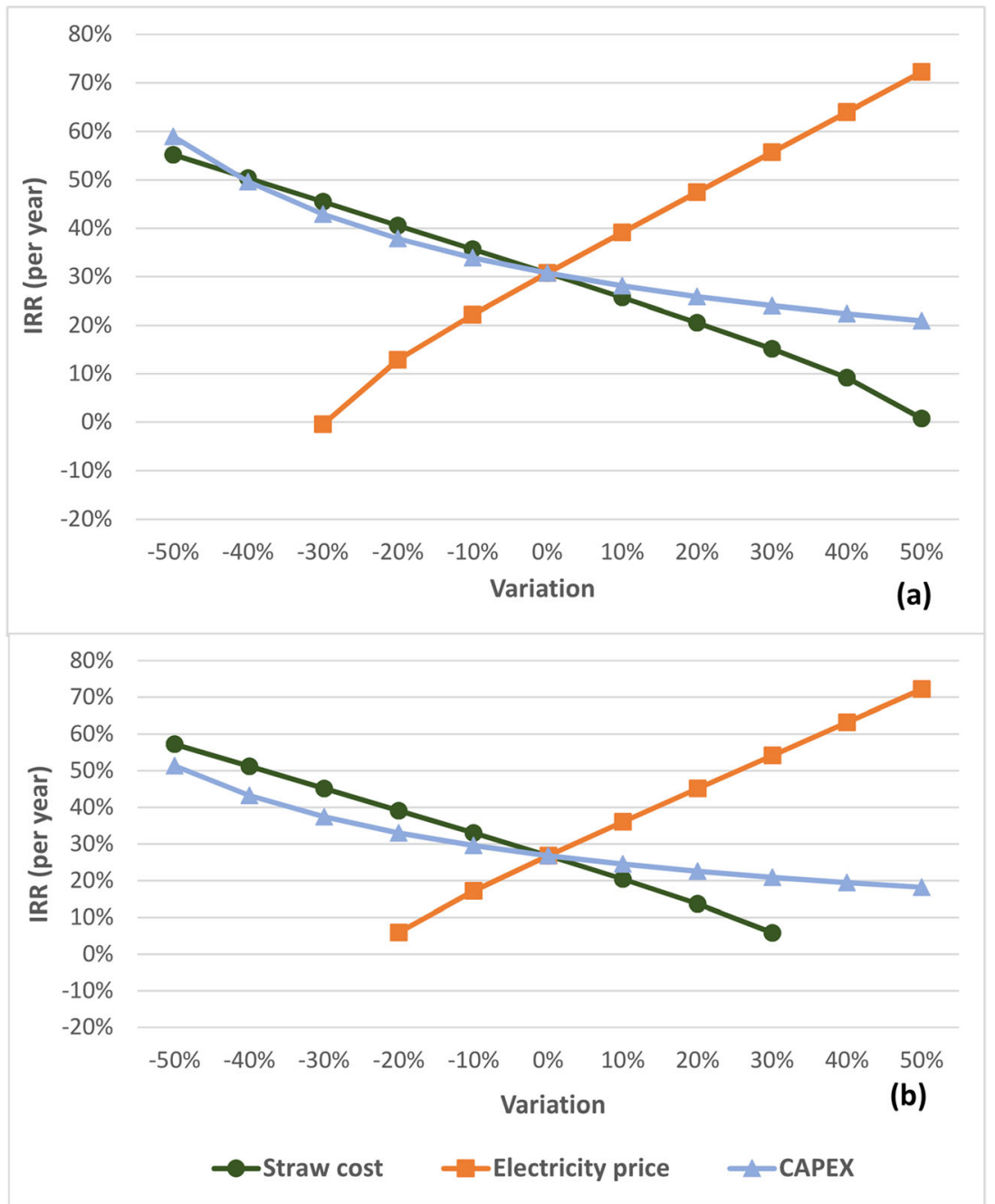

Fig. 5 Sensitivity analysis for the impact of straw cost, electricity price, and CAPEX on the internal rate of return for a scenario 1 and $\mathbf{b}$ scenario 2 . Points where IRR (\% per year) was not calculated were omitted 
Table 5 Sensitivity of IRR to changes in straw cost and electricity price for scenario 2 . Dash refers to cases where IRR (\% per year) was not calculated

\begin{tabular}{llllll}
\hline \multicolumn{5}{c}{} & \multicolumn{2}{l}{ Variation on straw cost } & & \\
\cline { 2 - 5 } & $-50 \%$ & $-25 \%$ & $0 \%$ & $25 \%$ & $50 \%$ \\
\hline $\begin{array}{l}\text { Variation on } \\
\text { electricity price }\end{array}$ & & & & & \\
& & & & & \\
$-50 \%$ & $10 \%$ & - & - & - & - \\
$-25 \%$ & $35 \%$ & $19 \%$ & $-5 \%$ & - & - \\
$0 \%$ & $57 \%$ & $42 \%$ & $27 \%$ & $10 \%$ & - \\
$25 \%$ & $80 \%$ & $65 \%$ & $50 \%$ & $34 \%$ & $19 \%$ \\
$50 \%$ & $102 \%$ & $87 \%$ & $72 \%$ & $57 \%$ & $42 \%$ \\
\hline
\end{tabular}

larger fuel consumption) and reduction of $\mathrm{N}_{2} \mathrm{O}$ emissions to air associated with lower amount of biomass decomposing in the field. The $\mathrm{N}_{2} \mathrm{O}$ emissions are calculated assuming $4.8 \mathrm{~kg}$ of nitrogen per tonne of straw (db) [35], considering direct $\mathrm{N}_{2} \mathrm{O}$ emission (1\% of nitrogen in straw) and emission from $\mathrm{NO}_{3}{ }^{-}\left(0.75 \%\right.$ of $\mathrm{N}$ in $\left.\mathrm{NO}_{3}{ }^{-}\right)$[36].

The difference in industrial emissions is due to a higher amount of lignocellulosic material (bagasse and straw) burnt on the boilers (scenarios 1 and 2), which increases $\mathrm{CH}_{4}$ and $\mathrm{N}_{2} \mathrm{O}$ emissions.

Since straw recovery makes possible to produce more electricity, the emissions are diluted among more products after allocation, which decreases the CI of electricity and ethanol compared with the baseline. Such differences on the attributional LCA results are translated in different CI for ethanol in the scenarios assessed, consequently higher avoided emissions (when replacing gasoline with ethanol, and electricity from natural gas with bioelectricity). The total avoided emissions are the multiplication of avoided emissions per amount of ethanol produced (Table 6) and electricity produced (Table 7).

In Fig. 6, the incremental avoided emissions of ethanol and electricity, possible due to straw recovery and processing in scenarios 1 and 2, are presented. The incremental avoided emissions associated with the replacement of gasoline with sugarcane ethanol are relatively small. This is because the amount of ethanol produced is constant in the three different scenarios and there is only a slight reduction in CI from one scenario to the other. On the other hand, the environmental advantages (incremental avoided emissions) of electricity generated from straw utilization and replacement of natural gas are more pronounced (20-fold, compared with ethanol mitigation), since there is additional electricity production and a larger difference between CI of both electricity sources.

\section{General Discussion}

\section{Straw Use in Power Generation}

The use of larger amounts of sugarcane straw as fuel imposes some restrictions on the boiler operations, due to characteristics and properties that differ from sugarcane bagasse, traditionally used as fuel in boilers. Bagasse is obtained after successive steps of sugarcane juice extraction, which ascribe specific moisture (around 50\%), low ash content, and uniform particle size, while straw, collected using baling system, presents high content of mineral impurities and ash in its composition and large variation of particle size.
Table 6 GHG emissions of ethanol and avoided emissions from gasoline replacement

\begin{tabular}{|c|c|c|c|}
\hline & Baseline & Scenario 1 & Scenario 2 \\
\hline Agricultural emissions $\left(\mathrm{g} \mathrm{CO}_{2} \mathrm{eq} / \mathrm{MJ} \mathrm{EtOH}\right)$ & 17.79 & 17.38 & 16.77 \\
\hline Industrial emissions ( $\left.\mathrm{g} \mathrm{CO}_{2} \mathrm{eq} / \mathrm{MJ} \mathrm{EtOH}\right)$ & 2.68 & 2.77 & 2.96 \\
\hline Distribution and use emissions ( $\left.\mathrm{g} \mathrm{CO}_{2} \mathrm{eq} / \mathrm{MJ} \mathrm{EtOH}\right)$ & 1.03 & 1.03 & 1.03 \\
\hline Ethanol CI ( $\left.\mathrm{g} \mathrm{CO}_{2} \mathrm{eq} / \mathrm{MJ}\right)$ & 21.50 & 21.18 & 20.76 \\
\hline Gasoline $\mathrm{CI}\left(\mathrm{g} \mathrm{CO}_{2} \mathrm{eq} / \mathrm{MJ}\right)$ & 87.4 & 87.4 & 87.4 \\
\hline Avoided emissions $^{\mathrm{a}}\left(\mathrm{g} \mathrm{CO}_{2} \mathrm{eq} / \mathrm{MJ}\right)$ & 65.90 & 66.22 & 66.64 \\
\hline Ethanol produced (TJ/year) & 4838.4 & 4838.4 & 4838.4 \\
\hline Total Avoided emissions ( $\mathrm{t} \mathrm{CO}_{2}$ eq/year) & 318,854 & 320,379 & 322,451 \\
\hline Incremental avoided emissions ${ }^{\mathrm{b}}$ ( $\mathrm{t} \mathrm{CO}_{2}$ eq/year) & - & 1525 & 3597 \\
\hline
\end{tabular}

${ }^{\text {a }}$ Compared with gasoline

${ }^{\mathrm{b}}$ Compared with the baseline. $1 \mathrm{t} \mathrm{CO}_{2}$ eq/year $=1 \mathrm{CBIO}$ 
Table 7 GHG emissions of biomass-based electricity and avoided emissions from natural gas replacement

\begin{tabular}{llll}
\hline & Baseline & Scenario 1 & Scenario 2 \\
\hline Agricultural emissions $\left(\mathrm{g} \mathrm{CO}_{2} \mathrm{eq} / \mathrm{kWh}\right)$ & 63.77 & 62.29 & 60.09 \\
Industrial emissions $\left(\mathrm{g} \mathrm{CO}_{2} \mathrm{eq} / \mathrm{kWh}\right)$ & 9.59 & 9.94 & 10.61 \\
Bioelectricity CI $\left(\mathrm{g} \mathrm{CO}_{2} \mathrm{eq} / \mathrm{kWh}\right)$ & 73.36 & 72.24 & 70.70 \\
Natural gas electricity $\left(\mathrm{g} \mathrm{CO}_{2} / \mathrm{kWh}\right)$ & 550.8 & 550.8 & 550.8 \\
Avoided emissions ${ }^{\mathrm{a}}\left(\mathrm{g} \mathrm{CO}_{2} \mathrm{eq} / \mathrm{kWh}\right)$ & 447.4 & 478.6 & 480.1 \\
Electricity produced $\left(\mathrm{GWh}_{\text {year})}\right.$ & 283.3 & 345.4 & 443.7 \\
Total avoided emissions $\left(\mathrm{t} \mathrm{CO}_{2} \mathrm{eq} /\right.$ year$)$ & 135,279 & 165,313 & 213,026 \\
Incremental avoided emissions $^{\mathrm{b}}\left(\mathrm{t} \mathrm{CO}_{2}\right.$ eq/year) & - & 30,034 & 77,747 \\
\hline
\end{tabular}

${ }^{\mathrm{a}}$ Compared with natural gas

${ }^{\mathrm{b}}$ Compared with the baseline
Nowadays, most of the sugarcane mills process straw and bagasse together, which are mixed in a feeder conveyor. The percentage of straw in relation to bagasse is still low, about 10 to $20 \%$ of the total mass of fuel fed into the boiler. Due to the high particle size and moisture content below 20\%, the straw presents a low density compared with sugarcane bagasse, which hinders the continuous feeding of the boiler for higher proportions of straw, causing load oscillations. Consequently, the boilers operate below its maximum capacity. In addition, the higher contents of mineral impurities and ash of straw cause fouling and slagging in the boilers.

The SUCRE Project [23] has evaluated these impacts and has been working on the proposition of alternatives to adequate straw quality in order to reduce the impacts on conventional boiler operation, allowing a better exploitation of this biomass for electricity generation in the industry.

\section{Incentives for Biofuels in Brazil}

Recently, a national program known as RenovaBio was approved in Brazil (Law No. 13,576, from December 26, 2017). This program is expected to be an incentive for biofuel production in the country (e.g., bioethanol, biodiesel, biomethane, biokerosene) in order to reduce GHG emissions and contribute to energy security [37]. Among the goals of RenovaBio are the contribution to Brazil's Nationally Determined Contributions (NDCs) under Paris Agreement; the incentive to expand biofuel contribution on the energy matrix and to increase energy efficiency; the reduction of GHG emissions of biofuel production, distribution, and use; and the predictability of fuel market [37].

The RenovaBio program aims to trade carbon credits (CBIO) generated by the decarbonization $\left(\mathrm{t} \mathrm{CO}_{2} \mathrm{eq}\right)$ possible
Fig. 6 Incremental avoided emissions (compared with the baseline) of straw recovery scenarios due to replacement of fossil alternatives

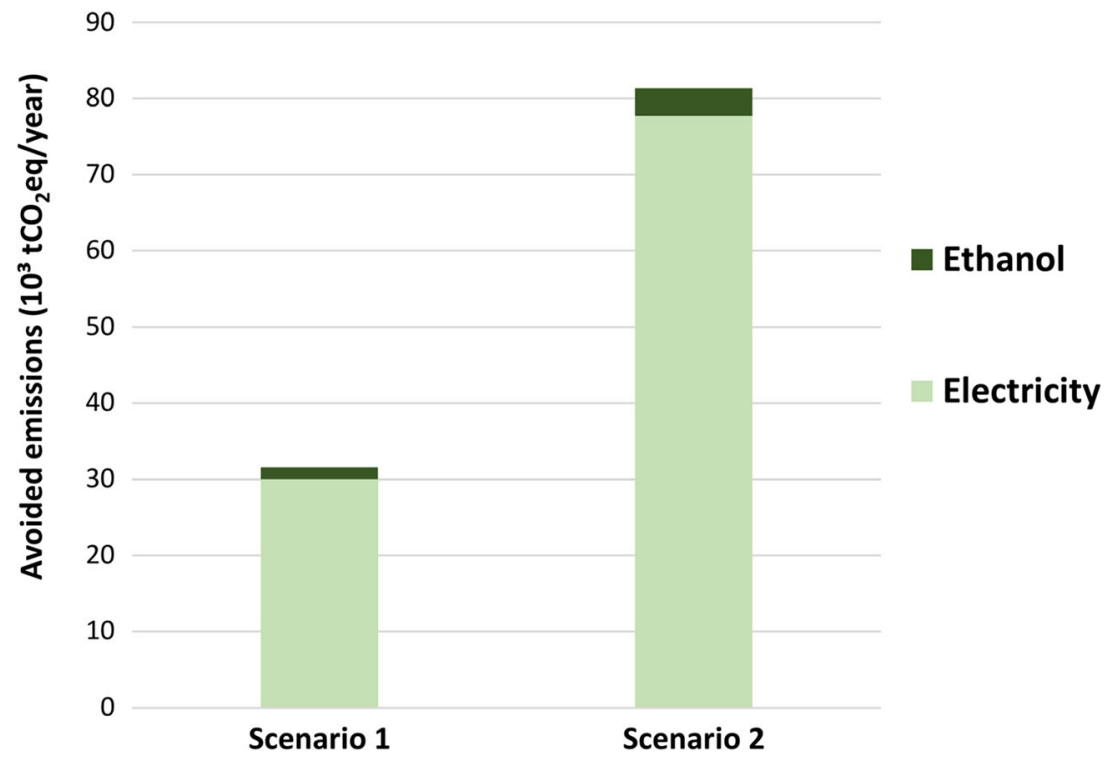


due to production and use of biofuels instead of fossil fuel. The CBIOs are calculated considering the $\mathrm{CI}$ of each biofuel in grams of $\mathrm{CO}_{2}$ eq per megajoule. Although the program is not a direct incentive to sugarcane bioelectricity expansion, the increase in electricity production would reduce the CI of ethanol and could generate economic benefits.

For scenario 2, the incremental avoided emissions associated with ethanol would translate to 3.6 thousand CBIOs that are the incremental avoided emissions presented in Table 6; these emissions are the difference of total avoided emissions from baseline and scenario 2 . Such difference among scenarios is due to a lower ethanol CI when recovering straw.

As CBIO will be traded in the stock market, there is no definition on its price. CBIO values around $\$ 10$ and as high as $\$ 43$ have been mentioned in discussions related to RenovaBio program. Considering the upper value and CBIO generation in scenario 2 , the impact on gross profit would be $7 \%$, IRR would increase 1.7 percentage points, and a reduction of $2 \%$ on MSP of electricity would be achieved. This indicates the positive indirect economic benefit of recovering additional straw to produce electricity, which, in turn, will reduce the emissions of ethanol.

\section{Conclusions}

The straw recovery costs with bales depend on the amount of straw recovered per hectare. The cost per tonne of straw decreases as the amount of straw recovered increases, due to a more efficient use of agricultural machinery. However, the definition of the amount of straw that can be recovered must consider possible agronomic effects, which depend upon climate and soil conditions, among other factors.

The utilization of straw as a complementary biomass for electricity generation allowed increasing surplus electricity by $22 \%$ (compared with the baseline) when recovering additional 9\% of the straw produced in the field. This amount would be processed in an existing sugarcane mill during the season in case of idle capacity of the cogeneration system. Larger amounts of straw could be processed by operating the cogeneration system also in the off-season period, resulting in an increase of $57 \%$ in electricity output associated with a $27 \%$ straw recovery.

Techno-economic assessment showed that straw recovery using bale system can be an economically feasible alternative for electricity generation. Despite that industrial investment associated with unbaling equipment of straw in the industry as well agricultural straw recovery costs impact the viability of electricity generation, the project feasibility indicated to be heavily sensitive to electricity prices. In this sense, although higher returns can be obtained from price peaks of the Brazilian short-term (spot) market, the project would be exposed to a higher risk. For this reason, an interesting alternative would be to trade a higher share of the additional electricity in both the Brazilian free and regulated contracting environments.

In addition, sugarcane ethanol and bioelectricity present environmental benefits compared with fossil sources of energy. The replacement of fossil fuels (i.e., gasoline and electricity from natural gas) by sugarcane-derived fuels (i.e., ethanol and bioelectricity) avoids GHG emissions. Straw recovery increases the environmental benefit by increasing electricity surplus. For instance, the total $\mathrm{CO}_{2}$ eq emissions avoided in scenario 2 are almost $20 \%$ higher than those in the baseline. Due to this mitigation potential, although the RenovaBio program and the CBIO market are still under implementation, it is expected that sugarcane straw recovery will bring environmental and economic benefits to the sugarcane sector in Brazil.

Another point to highlight is that using sugarcane straw as a feedstock to generate more electricity can also coexist with second-generation ethanol. In integrated plants, both ethanol and electricity can be produced. Analogously to the current flexibility between sugar and $1 \mathrm{G}$ ethanol production in the country, a flexibility between $2 \mathrm{G}$ ethanol and electricity might be observed depending upon market constraints such as electricity prices and CBIO market.

Finally, the retrofit projects for sugarcane straw utilization allow a gradual increase in the exploitation of this biomass, without having high capital costs associated with acquisition of equipment for cogeneration. Moreover, this approach allows reaching maturity of straw recovery and processing operations, making straw available in the industry not only for its use as fuel for electricity generation but also for its use as feedstock for other applications, such as production of biofuels and biochemicals.

Funding Information The research is financially supported by LNBR Brazilian Biorenewables National Laboratory (CNPEM/MCTIC) during the use of the Virtual Sugarcane Biorefinery open access facility. The research received funding from the Global Environment Facility (GEF) for the project BRA/10/G31 - "Sugarcane Renewable Electricity SUCRE" and United Nations Development Programme (UNDP) for management. The research also received financial support from the São Paulo Research Foundation - FAPESP (grant 2015/20630-4).

\section{Compliance with Ethical Standards}

Conflict of Interest The authors declare that they have no conflicts of interest.

Open Access This article is distributed under the terms of the Creative Commons Attribution 4.0 International License (http:// creativecommons.org/licenses/by/4.0/), which permits unrestricted use, distribution, and reproduction in any medium, provided you give 
appropriate credit to the original author(s) and the source, provide a link to the Creative Commons license, and indicate if changes were made.

\section{References}

1. Cardoso TF, Watanabe MDB, Souza A, Chagas MF, Cavalett O, Morais ER, Nogueira LAH, Leal MRegis LV, Braunbeck OA, Cortez LAB, Bonomi A (2018) Economic, environmental, and social impacts of different sugarcane production systems. Biofuels Bioprod Biorefin 12:68-82. https://doi.org/10.1002/bbb.1829

2. Menandro L, Cantarella H, Franco H, Kölln O, Pimenta M, Sanches G, Rabelo S, Carvalho J (2017) Comprehensive assessment of sugarcane straw: implications for biomass and bioenergy production. Biofuels Bioprod Biorefin 11:488-504. https://doi.org/10.1002/bbb.1760

3. CONAB (2018) Acompanhamento Safra Brasileira. Cana-de-açúcar, v. 5 - Safra 2018/19, n.3 - Terceiro levantamento. Brasília, p 1-71

4. Carvalho J, Nogueirol R, Menandro L, Bordonal R d O, Borges C, Cantarella H, Franco H (2017) Agronomic and environmental implications of sugarcane straw removal: a major review. GCB Bioenergy 9:1181-1195. https://doi.org/10.1111/gcbb.12410

5. Castioni G, Cherubin M, Menandro L, Sanches G, Bordonal R d O, Barbosa L, Franco H, Carvalho J (2018) Soil physical quality response to sugarcane straw removal in Brazil: a multi-approach assessment. Soil Tillage Res 184:301-309. https://doi.org/10.1016/j. still.2018.08.007

6. Awe G, Reichert J, Wendroth O (2015) Temporal variability and covariance structures of soil temperature in a sugarcane field under different management practices in southern Brazil. Soil Tillage Res 150:93-106. https://doi.org/10.1016/ j.still.2015.01.013

7. Dinardo-Miranda L, Fracasso J (2013) Sugarcane straw and the populations of pests and nematodes. Sci Agric 70:305-310. https://doi.org/10.1590/S0103-90162013000500012

8. Macedo N, Botelho P, Campos M (2003) Controle químico de cigarrinha da-raiz em cana-de-açúcar e impacto sobre a população de artrópodes. Stab Açúcar, Álcool e Subprodutos 21:30-33

9. Rossetto R, Cantarella H, Dias F, Landell M, Vitti A (2008) Manejo conservacionista e reciclagem de nutrientes em cana-de-açúcar tendo em vista a colheita mecânica. Informações Agronômicas 124:8-13

10. Marin F, Thorburn P, Costa L, Otto R (2014) Simulating long-term effects of trash management on sugarcane yield for Brazilian cropping systems. SugarTech 16:164-173. https://doi.org/10. 1007/s12355-013-0265-2

11. Alves M, Ponce G, Silva M, Ensinas A (2015) Surplus electricity production in sugarcane mills using residual bagasse and straw as fuel. Energy 91:751-757. https://doi.org/10.1016/j.energy.2015.08.101

12. Junqueira TL, Chagas MF, Gouveia VL, Rezende MCAF, Watanabe MDB, Jesus CDF, Cavalett O, Milanez A, Bonomi A (2017) Techno-economic analysis and climate change impacts of sugarcane biorefineries considering different time horizons. Biotechnol Biofuels 10(1):50. https://doi.org/10.1186/s13068017-0722-3

13. Rodriguez R, Manochio C, Moraes B (2018) Energy integration of biogas production in an integrated $1 \mathrm{G} 2 \mathrm{G}$ sugarcane biorefinery: modeling and simulation. Bioenergy Res 12:1-10. https://doi.org/ 10.1007/s12155-018-9950-Z

14. Silva J, Selicani M, Junqueira TL, Klein B, Vaz Júnior S, Bonomi A (2017) Integrated furfural and first generation bioethanol production: process simulation and techno-economic analysis. Braz $\mathrm{J}$
Chem Eng 34:623-634. https://doi.org/10.1590/0104-6632. 20170343s20150643

15. Klein B, Silva J, Junqueira TL, Rabelo S, Arruda P, Ienczak J, Mantelatto P, Pradella J, Vaz Júnior S, Bonomi A (2017) Process development and techno-economic analysis of bio-based succinic acid derived from pentoses integrated to a sugarcane biorefinery. Biofuels Bioprod Biorefin 11:1051-1064. https://doi.org/10.1002/ bbb. 1813

16. Cardoso TF, Chagas MF, Rivera E, Cavalett O, Morais E, Geraldo V, Braunbeck OA, Cunha M, Cortez LAB, Bonomi A (2015) A vertical integration simplified model for straw recovery as feedstock in sugarcane biorefineries. Biomass Bioenerg 81:216-223. https://doi.org/10.1016/j.biombioe.2015.07.003

17. Carvalho D, Veiga J, Bizzo W (2017) Analysis of energy consumption in three systems for collecting sugarcane straw for use in power generation. Energy 119:178-187. https://doi.org/10.1016/j.energy. 2016.12.067

18. Hassuani S, Leal M, Macedo I (2005) Biomass power generation. Sugarcane bagasse and trash. UNDP-UN and Centro de Tecnologia Canavieira-CTC, Piracicaba, Brazil

19. Lisboa I, Cherubin M, Lima R, Cerri C, Satiro L, Wienhold B, Schmer M, Jin V, Cerri C (2018) Sugarcane straw removal effects on plant growth and stalk yield. Ind Crops Prod 111:794-206. https://doi.org/10.1016/j.indcrop.2017.11.049

20. Teixeira M (2018) Banks see Brazil sugar sector shrinking on financial woes. https://www.reuters.com/article/brazil-sugarcompanies/update-1-banks-see-brazil-sugar-sector-shrinking-onfinancial-woes-idUSL2N1VQ0JI. Accessed March 2019

21. CCEE (Electric Energy Trading Chamber) (2018) Historical prices of electricity in the regulated market (auctions). https://www.ccee. org.br/. Accessed Nov 2018

22. MME - Brazilian Ministry of Mines and Energy (2014) Energy auctions. Ministry of Mines and Energy (MME) http://www.mme. gov.br/programas/leiloes_de energia/. Accessed July 2014

23. SUCRE Project (n.d.) Sugarcane renewable electricity. https:// pages.cnpem.br/sucre/. Accessed March 2019

24. Bonomi A, Cavalett O, Cunha MP, Lima MAP (2016) Virtual biorefinery - an optimization strategy for renewable carbon valorization. Springer International Publishing, Switzerland

25. Moraes BS, Junqueira TL, Pavanello LG, Cavalett O, Mantelatto PE, Bonomi A, Zaiat M (2014) Anaerobic digestion of vinasse from sugarcane biorefineries in Brazil from energy, environmental, and economic perspectives: profit or expense? Appl Energy 113:825835. https://doi.org/10.1016/j.apenergy.2013.07.018

26. Cavalett O, Chagas MF, Magalhães PSG, Carvalho JLN, Cardoso TF, Franco HCJ, Braunbeck OA, Bonomi A (2016) The agricultural production model. In: Bonomi A, Cavalett O, Cunha MP, Lima MAP (eds) Virtual biorefinery - an optimization strategy for renewable carbon valorization. Springer International Publishing, Switzerland, pp 13-51

27. Watanabe MDB, Pereira L, Chagas M, Cunha M, Jesus C, Souza A, Rivera E, Maciel Filho R, Cavalett O, Bonomi A (2016) Sustainability assessment methodologies. In: Bonomi A, Cavalett O, Cunha MP, Lima MAP (eds) Virtual biorefinery - an optimization strategy for renewable carbon valorization. Springer International Publishing, Switzerland, pp 155-188

28. Ecoinvent database (n.d.). https://www.ecoinvent.org/database/ database.html. Accessed Oct 2018

29. Matsuura MISF, Scachetti MT, Chagas MF, Seabra J, Moreira MMR, Bonomi A, Bayma G, Picoli JF, Morandi MAB, Ramos NP, Cavalett O, Novaes RML (2018) NOTA TÉCNICA RenovaCalcMD: Método e ferramenta para a contabilidade da 
Intensidade de Carbono de Biocombustíveis no Programa RenovaBio. http://www.anp.gov.br/images/Consultas_publicas/ 2018/n10/CP10-2018_Nota-Tecnica-Renova-Calc.pdf. Accessed March 2019

30. Magalhães PSG, Nogueira LAH, Cantarella H, Rossetto R, Franco HCJ, Braunbeck OA (2012) Agro-industrial technological paths. In: Poppe MK, Cortez LAB (eds) Sustainability of sugarcane bioenergy. Center of Strategic Studies and Management (CGEE), Brasília, pp 27-69

31. Dias M, Junqueira TL, Sampaio I, Chagas M, Watanabe MD, Morais E, Gouveia V, Klein B, Rezende MC, Cardoso TF, Souza A, Jesus C, Pereira L, Rivera E, Maciel Filho R, Bonomi A (2016) Use of the VSB to assess biorefinery strategies. In: Bonomi A, Cavalett O, Cunha MP, Lima MAP (eds) Virtual biorefinery - an optimization strategy for renewable carbon valorization. Springer International Publishing, Switzerland, pp 189-256

32. Olivério JL, Ferreira F (2010) A new source of income for sugar and ethanol mills or bioelectricity - a new business. Proc Int Soc Sugar Cane Technol 27:1-13

33. Bizzo W, Lenço P, Carvalho D, Veiga J (2014) The generation of residual biomass during the production of bio-ethanol from sugarcane, its characterization and its use in energy production. Renew Sust Energ Rev 29:589-603. https://doi.org/10.1016/j.rser.2013.08.056

34. PECEGE - Continuing Education Program in Economics and Agribusiness Management (2014) Custos de cana de açúcar, etanol e bioeletricidade no Brasil - Fechamento da safra 2013/2014. College of Agriculture "Luiz de Queiroz", University of São Paulo

35. Franco H (2008) Eficiência agronômica da adubação nitrogenada de cana planta. Thesis, College of Agriculture "Luiz de Queiroz", University of São Paulo

36. IPCC IP on CC (2006) Guidelines for national greenhouse gas inventories, Vol. 4 - Agriculture, forestry and other land use. Intergovernmental Panel on Climate Change. https://www.ipccnggip.iges.or.jp/public/2006gl/vol4.html. Accessed Jan 2019

37. MME - Brazilian Ministry of Mines and Energy (2019) Renovabio. http://www.mme.gov.br/web/guest/secretarias/petroleo-gasnatural-e-combustiveis-renovaveis/programas/renovabio/principal. Accessed March 2019

Publisher's Note Springer Nature remains neutral with regard to jurisdictional claims in published maps and institutional affiliations. 